\title{
Evaluation of Hydrogenation Kinetics and Life Cycle Assessment on $\mathrm{Mg}_{2} \mathrm{NiH}_{\mathrm{x}}-\mathrm{CaO}$ Composites
}

\author{
Hyo-Won Shin $\mathbb{1}^{(0)}$, June-Hyeon Hwang, Eun-A Kim $\mathbb{1}$ and Tae-Whan Hong * \\ Department of Materials Science and Engineering, College of Engineering, \\ Korea National University of Transportation, Chungju 27469, Korea; whun2288@ut.ac.kr (H.-W.S.); \\ hj930403@ut.ac.kr (J.-H.H.); euna_0106@ut.ac.kr (E.-A.K.) \\ * Correspondence: twhong@ut.ac.kr; Tel.: +82-43-841-5388
}

Citation: Shin, H.-W.; Hwang, J.-H.; Kim, E.-A.; Hong, T.-W. Evaluation of Hydrogenation Kinetics and Life Cycle Assessment on $\mathrm{Mg}_{2} \mathrm{NiH}_{\mathrm{x}}-\mathrm{CaO}$ Composites. Materials 2021, 14, 2848. https://doi.org/10.3390/ma 14112848

Academic Editors: Ute Kalbe and Franz-Georg Simon

Received: 27 April 2021

Accepted: 24 May 2021

Published: 26 May 2021

Publisher's Note: MDPI stays neutral with regard to jurisdictional claims in published maps and institutional affiliations.

Copyright: (C) 2021 by the authors. Licensee MDPI, Basel, Switzerland. This article is an open access article distributed under the terms and conditions of the Creative Commons Attribution (CC BY) license (https:/ / creativecommons.org/licenses/by/ $4.0 /)$.

\begin{abstract}
Magnesium-based alloys are attractive as hydrogen storage materials due to their lightweight and high absorption, but their high operating temperatures and very slow kinetics are obstacles to practical applications. Therefore, the effect of $\mathrm{CaO}$ has improved the hydrogenation kinetics and slowed down the degradation. The $\mathrm{Mg}_{2} \mathrm{NiH}_{\mathrm{x}}-\mathrm{CaO}$ composites were prepared by hydrogeninduced mechanical alloying (HIMA). Hydrogenation kinetics was performed by using an Automatic PCT Measuring System and evaluated in the temperature range of 423, 523, and $623 \mathrm{~K}$. As a result of calculating the hydrogen absorption amounts through the hydrogenation kinetics curve, they were calculated as about $0.52 \mathrm{wt} \%, 1.21 \mathrm{wt} \%$, and $1.59 \mathrm{wt} \%\left(\mathrm{Mg}_{2} \mathrm{NiH}_{\mathrm{x}}-10 \mathrm{wt} \% \mathrm{CaO}\right)$. In this study, the material environmental aspects of $\mathrm{Mg}_{2} \mathrm{NiH}_{\mathrm{x}}-\mathrm{CaO}$ composites were investigated through life cycle assessment (LCA). LCA was performed analyzing the environmental impact characteristics of the manufacturing process by using Gabi software and the Eco-Indicator 99' and Centrum voor Milieuweten schappen (CML 2001) methodology. As a result, the contents of global warming potential (GWP) and fossil fuels were found to have a higher impact than other impact categories.
\end{abstract}

Keywords: hydrogen storage; kinetics; material life cycle assessment; Eco-Indicator 99'; CML 2001

\section{Introduction}

Recently, due to greenhouse gas emissions and global warming problems, the need to develop a new and renewable energy source that can replace fossil fuels has increased, and hydrogen, a clean energy media, has attracted attention [1]. Hydrogen is known as a clean energy media because, unlike fossil fuels, it cannot be used directly in nature, and it is produced from primary energy sources to produce energy through internal combustion engines or fuel cells, and only water is produced as a by-product [2,3]. Accordingly, in January 2019, the government announced the "Hydrogen Economy Revitalization Roadmap" to realize a zero-carbon society and lead the transformation of the energy paradigm by utilizing hydrogen with a high energy storage density $\left(33.3 \mathrm{kWh} / \mathrm{kg} \mathrm{H}_{2}\right)$. To realize these hydrogen economies, technological innovation in the production, storage, transportation, and utilization of hydrogen are necessary. However, in the case of hydrogen storage technology, which is essential for safely storing and transporting hydrogen, secure technology is urgently needed because investment is not made relatively [4].

Among the hydrogen storage methods, metal hydrides belonging to hydrogen storage alloys are produced by the reaction between metal and hydrogen, and the metal adsorbs hydrogen gas, and when heated again, it releases hydrogen. The reaction in which hydrogen reacts with a metal to form metal hydride (MH) is an exothermic reaction [5]. In particular, Mg-based hydride has the advantages of having high hydrogen storage, a low cost, and being lightweight. The surface is thermodynamically stable and has a very slow hydrogenation reaction rate [6-8].

To improve these obstacles, studies on the catalytic effect were conducted by adding a transition metal, and in the case of metal hydride $\left(\mathrm{Mg}_{2} \mathrm{NiH}_{4}\right)$, in order to change the 
thermodynamic stability, there have been studies on improving the storage and release characteristics of hydrogen by substituting various elements such as $\mathrm{Ca}$ and rare earth metals for $\mathrm{Mg}$ and $\mathrm{Ni}$ in the $\mathrm{Mg}_{2} \mathrm{Ni}$ alloy [9]. In this study, $\mathrm{Mg}_{2} \mathrm{NiH}_{\mathrm{x}}-\mathrm{CaO}$ composites were prepared by adding $\mathrm{CaO}$ to $\mathrm{Mg}_{2} \mathrm{NiH}_{\mathrm{x}}$ using hydrogen-induced mechanical alloying (HIMA). The effect of catalyst and oxidation resistance was investigated by paying attention to the hydrogenation behavior according to the added alkaline earth metal oxide.

Life cycle assessment (LCA) is an input and output to assess the environmental impact of a product or service throughout the entire process (raw material collection, product production, use, disposal), that is, resource depletion due to inputs, and environmental impacts caused by discharges. It can be said that it is a process of reviewing alternatives to improve environmental performance by preparing a quantitative data list of the data, evaluating the environmental impact [10]. In addition, as it forms the technical basis of the ISO 14000 series, it can be said to be an internationally important technique [11]. These results enable a fair comparison of products or processes and can also contribute to product design that minimizes environmental impact. Problems related to toxic emissions or waste can be solved by replacing materials or processes, as well as effects related to raw materials and energy consumed [12]. While LCA is a valuable way to measure environmental loads such as "cradle-to-grave", it has limitations when it comes to obtaining and evaluating data about the entire production process. LCA uses an internationally standardized methodological framework for analyzing the environmental impacts associated with the life cycle phases of products, processes, or activities over their entire life, typically from cradle-to-grave [13]. All products are made from materials, and one material is made using different technologies or used in different products [14]. Material life cycle assessment literally provides an important tool for material research as an environmental evaluation method that focuses on materials rather than processes. There is a case in which the potential environmental impact of recycling of indium tin oxide (ITO) transparent electrodes separated from the display panel has been studied with this material-focused environmental evaluation method [15]. Therefore, in this study, LCA was carried out to confirm that the hydrogenation kinetics of the $\mathrm{Mg}_{2} \mathrm{NiH}_{\mathrm{x}}-\mathrm{CaO}$ composites were improved and to evaluate the potential environmental impact of the material.

\section{Experimental Procedure}

\subsection{Specimen Preparation and Characterization}

Mg (Sigma-Aldrich, St. Louis, MO, USA, 98\%) and Ni (Sigma-Aldrich, St. Louis, MO, USA, $99.7 \%$ ) powder was charged into a 1/2-inch STS304 container. At this time, the weight ratio of $\mathrm{Mg}$ and $\mathrm{Ni}$ powder was designed as 45:55 with reference to the $\mathrm{Mg}-\mathrm{Ni}$ binary phase diagram. After making a vacuum up to $5 \times 10^{-2}$ Torr using a rotary pump, hydrogen of $99.9999 \%$ purity was applied to a pressure of $3.0 \mathrm{MPa}$ and alloyed for $96 \mathrm{~h}$ at a rotational speed of $200 \mathrm{rpm}$ using a planetary ball mill (Pulverisette-5, FRITSCH Co., Idar-Oberstein, Germany), which is a hydrogen-induced mechanical alloying method. At this time, the ball to chips weight ratio (BCR) of 1/2-inch chrome steel balls and magnesium chips was set to $66: 1$ with reference to the preceding paper [16]. Then, the prepared powder and 5 , $10 \mathrm{wt} \% \mathrm{CaO}$ (Sigma-Aldrich, 99.7\%) in the form of powder were charged into a container and alloyed for $24 \mathrm{~h}$ at a rotation speed of $200 \mathrm{rpm}$ under the same conditions.

For the metallurgical characterization of the sample prepared through the alloying process, the crystal structure and phase of the sample were characterized using X-ray diffraction (XRD) analysis (D8 Advance, Bruker, Billerica, MA, USA), which was performed using a Cu K $\alpha$ radiation of $1.5405 \AA$ (scanning speed: $3 \mathrm{deg} / \mathrm{min}$, scanning angle: $20-80^{\circ}$ ). In order to observe the surface shape and particle size of the sample according to the alloying time, it was observed using scanning electron microscopy (SEM) (FEI Quanta 400, FEI, Hillsboro, OR, USA), and Brunauer-Emmett-Teller (BET) surface analysis (Micromeritics-3-Flex, Heidelberg, Germany) was used to measure the particle specific surface area, which has a large influence on hydrogen diffusion. After that, the dehydrogenation activation energy was measured by drawing an Arrhenius plot through the dehydrogenation temperature. 
In addition, Sivert's type automatic PCT (pressure-composition-temperature) method, an automated volumetric measurement method, was used to measure the hydrogenation kinetics, and the hydrogen absorption reaction rate was evaluated at a temperature range of 423,523 , and $623 \mathrm{~K}$ for $1 \mathrm{~h}$ by applying a constant hydrogen pressure of 3.0 MPa.

\subsection{Life Cycle Assessment ( $L C A)$}

The LCA is used to analyze the environmental impact of a product and can provide information on the stages of a product's life cycle [17]. LCA has an ISO standardization method (ISO 14040 2006; ISO 14044 2006), an LCA consists of four categories: (1) goal and scope definition, (2) life cycle inventory analysis, (3) impact assessment and (4) interpretation of results $[18,19]$. The quality of the LCA depends on the exact description of the production process to be analyzed. To know where each phase of the life cycle begins and ends properly, you need to collect and interpret its process data. The study used the Centrum voor Milieuweten schappen (CML 2001), a combined lifecycle impact assessment method developed by the University of Leiden to determine the environmental performance of the process under study. The CML method defines several impact categories for emissions and resource consumption as problem-oriented (midpoint).

\subsubsection{Goal and Scope}

The goal and scope outline the material to be studied, assess the environmental impact categories, and analyze the resulting limitations or assumptions. First of all, it is very important to first establish the decisions to be presented by the evaluation for material selection [20]. The life cycle inventory (LCI) consists of identifications of all unit processes, product-related flows [13]. Additionally, the methodology adopted for LCA analysis in this study complies with the following standards [21]:

ISO 14040, 14044: 2006—Environmental Management—Life Cycle AssessmentRequirements and Guidelines [18,19].

In this study, a cradle-to-gate approach of LCA was applied to assess $\mathrm{Mg}_{2} \mathrm{NiH}_{\mathrm{x}}-5$, $10 \mathrm{wt} \% \mathrm{CaO}$ composites that were manufactured and characterized, and an environmental assessment was carried out throughout the disposal process. The goal is to identify whether hydrogenation kinetics is improved by adding $\mathrm{CaO}$ in the synthesis process of $\mathrm{Mg}_{2} \mathrm{NiH}_{\mathrm{x}}-\mathrm{CaO}$ composites, and quantify the resulting environmental load, and analyze the environmental characteristics.

The function of the prepared $\mathrm{Mg}_{2} \mathrm{NiH}_{\mathrm{x}}-\mathrm{CaO}$ composites are the hydrogenation kinetics, and the functional unit, which is a unit representing the function, is set as hydrogen content $(\mathrm{wt} \%)$, and the reference flow that satisfies the functional unit is $10 \mathrm{~g}$ of powder. Figure 1 is composed of a manufacturing step, a characteristic evaluation step, and a disposal step of the $\mathrm{Mg}_{2} \mathrm{NiH}_{\mathrm{x}}-\mathrm{CaO}$ composites in the LCA. The raw material category includes $\mathrm{Mg}_{2} \mathrm{Ni}$ and $\mathrm{CaO}$. The energy category includes electricity used in the manufacturing and characterization stages, and air emissions are carbon monoxide (CO), carbon dioxide $\left(\mathrm{CO}_{2}\right)$, sulfur oxides $\left(\mathrm{SO}_{\mathrm{x}}\right)$, nitrogen oxides $\left(\mathrm{NO}_{\mathrm{x}}\right)$, and dust generated throughout the process. Data quality requirements were established by dividing the technical, temporal and regional scope into manufacturing, characterization, and disposal stages.

\subsubsection{Impact Assessment Categories and Environmental Impact Methodology}

In this study, the end-point concept CML 2001 methodology and Eco-Indicato'99 (EI99) methodology developed by Nederland and pre-consulting organizations were used. In this study, the CML 2001 and Eco-Indicator 99' (EI99) methodology with an end-point concept developed by a Dutch pre-consulting institution were used, and these are shown in Tables 1 and 2. The software Gabi 6 (Sphera, Stuttgart, AR, USA) was used to perform an environmental impact assessment on the process of synthesizing the composites. The EI99 methodology considers three damage categories: human health, ecosystem health, and resources, of which, the following types of damage are sorted into: carcinogenic, respiratory effects, climate change, radioactivity, ozone layer, ecotoxicity, acidification, land 
use, resource, and fuel replenishment. As an indicator, in the human health category, the index of the endpoint level is derived using the disability-adjusted life years (DALY) as an indicator. It is expressed as the probability (PDF $\times \mathrm{m}^{2} \times \mathrm{yr}$ ) of the potential disappearance of species per area $\left(\mathrm{m}^{2}\right)$, and in the resource depletion category, the surplus energy input to harvest $1 \mathrm{~kg}$ of resources is selected as an indicator [22].

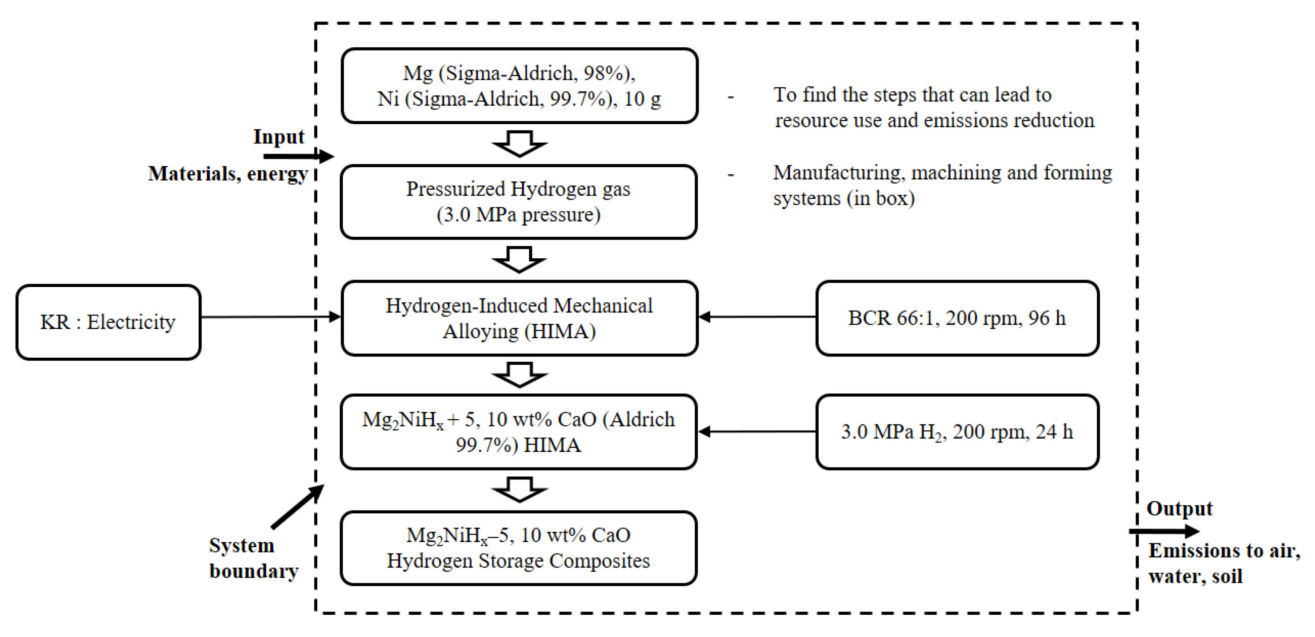

Figure 1. Process flow diagram for $\mathrm{Mg}_{2} \mathrm{NiH}_{\mathrm{x}}-5,10 \mathrm{wt} \% \mathrm{CaO}$ synthesis and analyses.

Table 1. Environmental impact categories applied using CML 2001.

\begin{tabular}{|c|c|c|c|}
\hline \multirow{2}{*}{ Environmental Impact Categories } & \multirow{2}{*}{ Unit } & \multicolumn{2}{|c|}{ Life Cycle Environmental Impacts } \\
\hline & & $\mathrm{Mg}_{2} \mathrm{NiH}_{\mathrm{x}}-5 \mathrm{wt} \% \mathrm{CaO}$ & $\mathrm{Mg}_{2} \mathrm{NiH}_{\mathrm{x}}-10 \mathrm{wt} \% \mathrm{CaO}$ \\
\hline Abiotic Resource Depletion (ARD) & $\mathrm{Kg} \mathrm{yr}^{-1}$ & $6.85 \times 10^{-3}$ & $8.76 \times 10^{-3}$ \\
\hline Global Warming Potential (GWP) & $\mathrm{Kg} \mathrm{CO}_{2}$ eq & $3.86 \times 10^{-2}$ & $4.09 \times 10^{-2}$ \\
\hline Stratospheric Ozone Depletion Potential (ODP) & $\mathrm{Kg} \mathrm{CFC}^{-11} \mathrm{eq}$ & $1.69 \times 10^{-5}$ & $2.57 \times 10^{-5}$ \\
\hline Photochemical Oxidation Potential (POCP) & $\mathrm{Kg} \mathrm{C}_{2} \mathrm{H}_{4} \mathrm{eq}$ & $1.41 \times 10^{-5}$ & $3.64 \times 10^{-5}$ \\
\hline Acidification Potential (ACP) & $\mathrm{Kg} \mathrm{SO}_{2} \mathrm{eq}$ & $1.83 \times 10^{-2}$ & $1.45 \times 10^{-2}$ \\
\hline Eutrophication Potential (EUP) & $\mathrm{Kg} \mathrm{PO}_{4}$ eq & $5.14 \times 10^{-3}$ & $5.69 \times 10^{-3}$ \\
\hline Fresh-water Aquatic Ecotoxicity Potential (FAETP) & $\mathrm{Kg} 1,4-\mathrm{DCB}$ eq & $1.57 \times 10^{-8}$ & $2.25 \times 10^{-8}$ \\
\hline Marine Aquatic Ecotoxicity Potential (MAETP) & $\mathrm{Kg} 1,4-\mathrm{DCB}$ eq & $1.89 \times 10^{-8}$ & $3.17 \times 10^{-8}$ \\
\hline Terrestrial Ecotoxicity Potential (TETP) & $\mathrm{Kg} 1,4-\mathrm{DCB}$ eq & $3.14 \times 10^{-4}$ & $5.33 \times 10^{-4}$ \\
\hline Human Toxicity Potential (HTP) & Kg 1,4-DCB eq & $7.25 \times 10^{-8}$ & $7.74 \times 10^{-8}$ \\
\hline
\end{tabular}

Table 2. Environmental impact categories Eco-Indicator 99' (EI99).

\begin{tabular}{|c|c|c|c|c|}
\hline \multirow{2}{*}{\multicolumn{2}{|c|}{ Damage Categories }} & \multirow{2}{*}{ Damage Unit } & \multicolumn{2}{|c|}{ Life Cycle Environmental Impacts } \\
\hline & & & $\mathrm{Mg}_{2} \mathrm{NiH}_{\mathrm{x}}-5 \mathrm{wt} \% \mathrm{CaO}$ & $\mathrm{Mg}_{2} \mathrm{NiH}_{\mathrm{x}}-10 \mathrm{wt} \% \mathrm{CaO}$ \\
\hline \multirow{6}{*}{ Human health } & Carcinogenic effect & DALY & $1.12 \times 10^{-8}$ & $1.63 \times 10^{-8}$ \\
\hline & Respiratory (organic) & DALY & $2.47 \times 10^{-8}$ & $2.68 \times 10^{-8}$ \\
\hline & Respiratory (inorganic) & DALY & $2.98 \times 10^{-2}$ & $5.02 \times 10^{-2}$ \\
\hline & Climate change & DALY & $1.16 \times 10^{-1}$ & $1.48 \times 10^{-1}$ \\
\hline & Ionizing radiation & DALY & $2.03 \times 10^{-2}$ & $2.15 \times 10^{-2}$ \\
\hline & Ozone depletion & DALY & $1.26 \times 10^{-8}$ & $1.29 \times 10^{-8}$ \\
\hline \multirow{3}{*}{$\begin{array}{l}\text { Ecosystem } \\
\text { quality }\end{array}$} & Ecotoxicity & $\mathrm{PDF} \times \mathrm{m}^{2} \times \mathrm{yr}$ & $1.32 \times 10^{-2}$ & $2.11 \times 10^{-2}$ \\
\hline & Acidification/Eutrophication & $\mathrm{PDF} \times \mathrm{m}^{2} \times \mathrm{yr}$ & $1.84 \times 10^{-2}$ & $1.95 \times 10^{-2}$ \\
\hline & Land-use & $\mathrm{PDF} \times \mathrm{m}^{2} \times \mathrm{yr}$ & $1.16 \times 10^{-2}$ & $1.19 \times 10^{-2}$ \\
\hline \multirow{2}{*}{ Resources } & Minerals & MJ & $1.73 \times 10^{-2}$ & $1.82 \times 10^{-2}$ \\
\hline & Fossil & MJ & $2.71 \times 10^{-1}$ & $3.18 \times 10^{-1}$ \\
\hline
\end{tabular}




\section{Results and Discussion}

\subsection{Evaluation of the Synthesized Composites}

Figure 2 shows the XRD pattern of the $\mathrm{Mg}_{2} \mathrm{NiH}_{\mathrm{x}}-10 \mathrm{wt} \% \mathrm{CaO}$ composites, which was ball-milled for $96 \mathrm{~h}$ in a hydrogen atmosphere to prepare $\mathrm{Mg}_{2} \mathrm{NiH}_{\mathrm{x}}$, and then ball-milled for an additional $24 \mathrm{~h}$ by adding $5,10 \mathrm{wt} \% \mathrm{CaO}$. As a result of the analysis, clear peaks of magnesium hydride and calcium oxide appeared, and $\mathrm{Mg}_{2} \mathrm{NiH}, \mathrm{Mg}_{2} \mathrm{NiH}_{4}$, and $\mathrm{CaO}$ peaks were identified through the International Centre for Diffraction Data (ICDD). Additionally, $\mathrm{Mg}_{2} \mathrm{NiH}_{4}$ has a monoclinic structure, and $\mathrm{Mg}_{2} \mathrm{NiH}$ and $\mathrm{CaO}$ have a cubic structure.

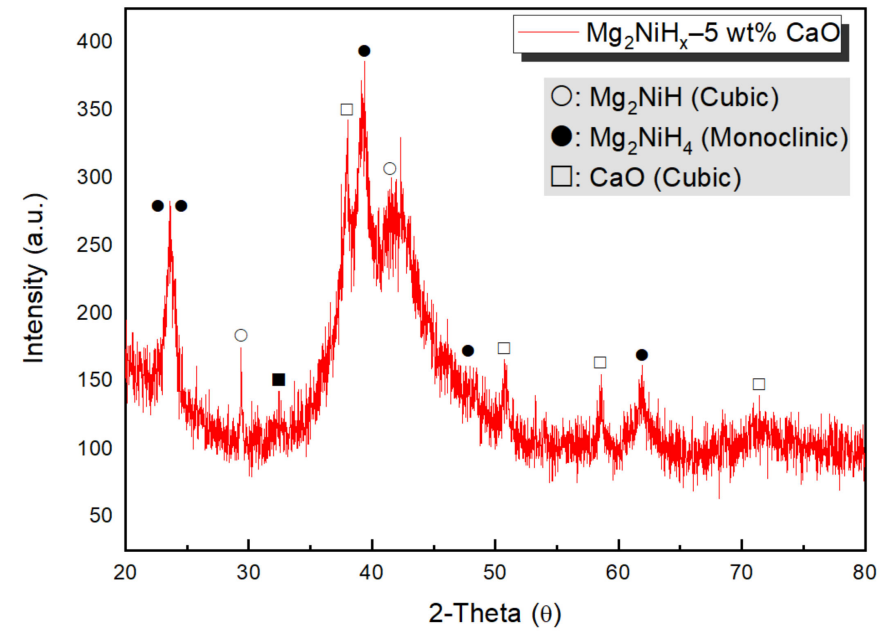

(a)

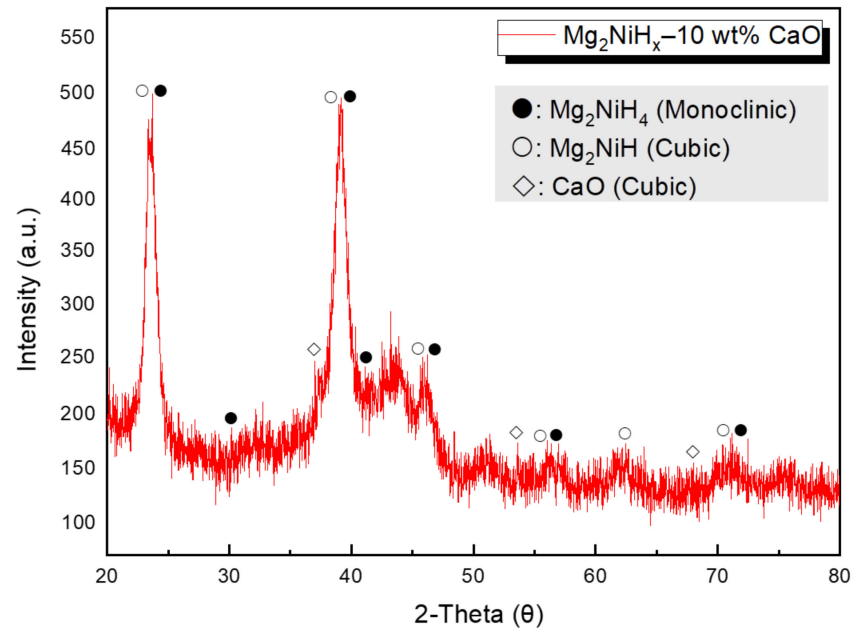

(b)

Figure 2. (a) $\mathrm{Mg}_{2} \mathrm{NiH}_{\mathrm{x}}-5 \mathrm{wt} \% \mathrm{CaO}$ (reprinted with permission from. [23]. Copyright 2021. Copyright Shin, H.-W.), (b) $\mathrm{Mg}_{2} \mathrm{NiH}_{\mathrm{x}}-10 \mathrm{wt} \% \mathrm{CaO}$ composites X-ray diffraction (XRD) image.

Figure 3 is a scanning electron microscope (SEM) surface shape observation photograph of $\mathrm{Mg}_{2} \mathrm{NiH}_{\mathrm{x}}-\mathrm{CaO}$ composites. Particle sizes vary from 1 to $10 \mu \mathrm{m}$ and a tendency to clumping has been observed due to the many nano-sized particles and the grinding process. It was pointed out that this cluster formation and irregular shape of the particle size distribution are evidence of the milling effect [24]. According to Huang et al., who studied the relationship between particle size and hydrogen diffusion, nano-sized particles and an increase in specific surface area promoted hydrogen absorption and desorption [25]. As a result of comparing the $\mathrm{Mg}_{2} \mathrm{NiH}_{\mathrm{x}}-5 \mathrm{wt} \% \mathrm{CaO}$ and $\mathrm{Mg}_{2} \mathrm{NiH}_{\mathrm{x}}-10 \mathrm{wt} \% \mathrm{CaO}$ composites, it can be seen that the particle size decreases as $\mathrm{CaO}$ is added. As the particle size decreases, the diffusion length of hydrogen decreases and the reaction surface area increases, so it is considered to be easier for hydrogen absorption and desorption.

Figure 4 is the result of specific surface area analysis (SSA) measuring the nitrogen absorption and desorption behavior of $\mathrm{Mg}_{2} \mathrm{NiH}_{\mathrm{x}}-\mathrm{CaO}$ composites, and $\mathrm{SSA}$ is calculated as $2.955 \mathrm{~m}^{2} / \mathrm{g}\left(\mathrm{Mg}_{2} \mathrm{NiH}_{\mathrm{x}}-5 \mathrm{wt} \% \mathrm{CaO}\right.$ [23]), $3.773 \mathrm{~m}^{2} / \mathrm{g}\left(\mathrm{Mg}_{2} \mathrm{NiH}_{\mathrm{x}}-10 \mathrm{wt} \% \mathrm{CaO}\right)$. Increasing the SSA of nanoparticles promote absorption and desorption of hydrogen but increases the alloying time and decreases the size of the particles, increasing the formation of nano and amorphous phases [26]. Comparing the $\mathrm{Mg}_{2} \mathrm{NiH}_{\mathrm{x}}-5,10 \mathrm{wt} \% \mathrm{CaO}$ composites, the specific surface area increases with the addition of $\mathrm{CaO}$, and thus the absorption and desorption behavior of hydrogen is expected to be advantageous. 


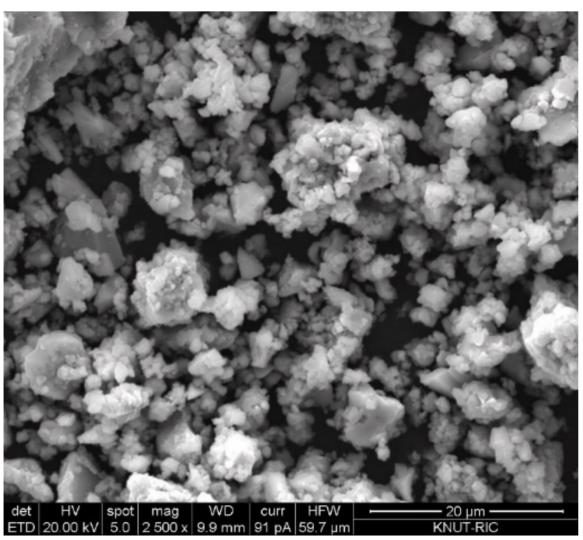

(a)

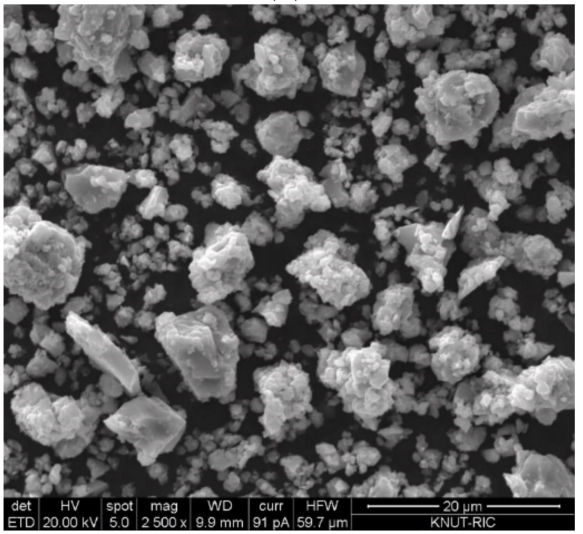

(d)

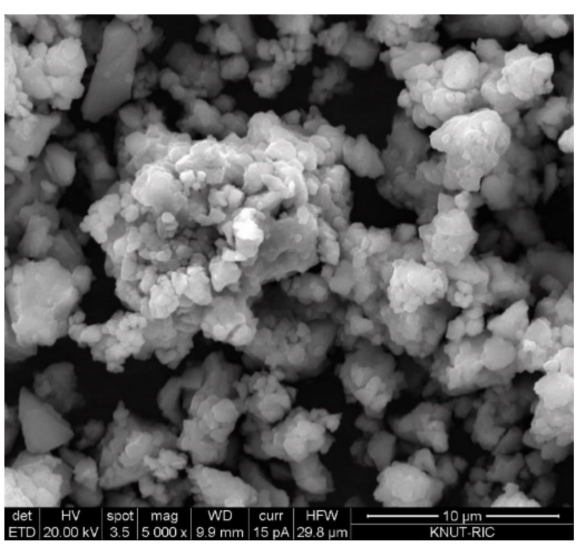

(b)

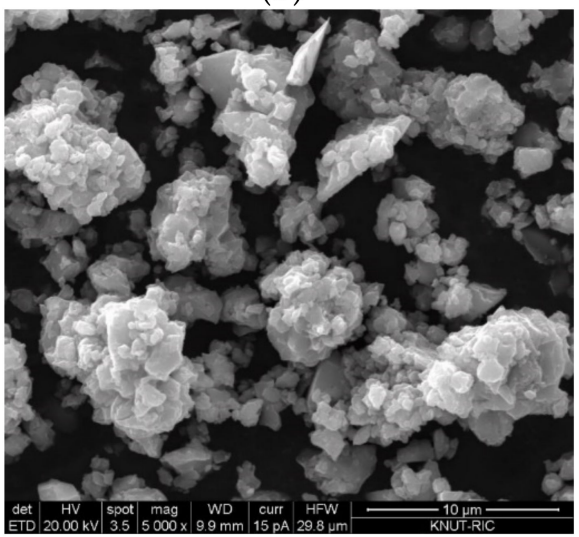

(e)

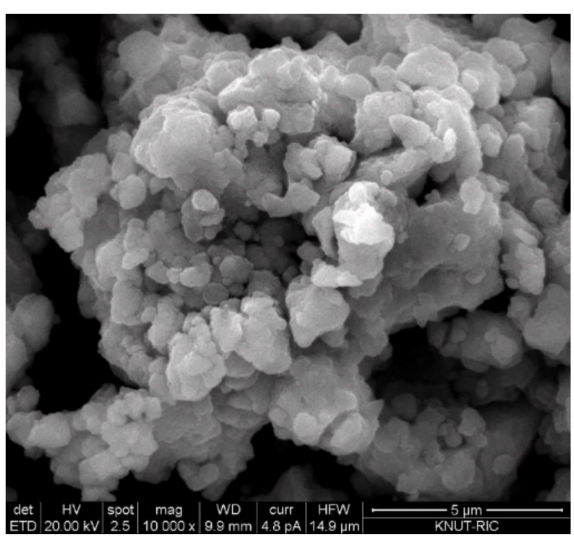

(c)

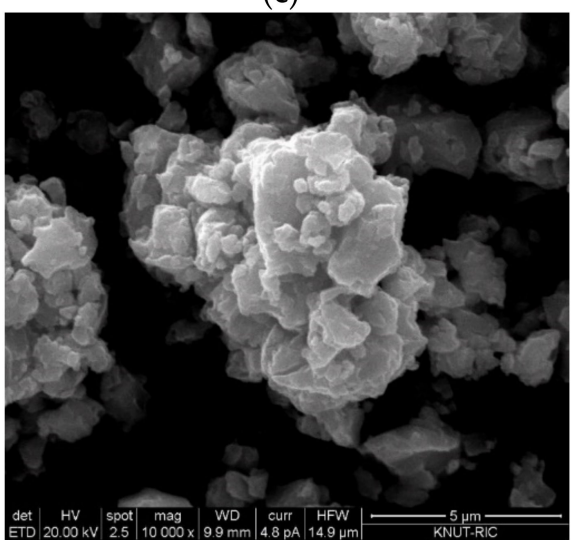

(f)

Figure 3. $\mathrm{Mg}_{2} \mathrm{NiH}_{\mathrm{x}}-5 \mathrm{wt} \% \mathrm{CaO}$ (reprinted with permission from [23]. Copyright 2021. Copyright Shin, H.-W.). SEM morphologies: (a) $\times 2500$, (b) $\times 5000$, (c) $\times 10,000, \mathrm{Mg}_{2} \mathrm{NiH}_{\mathrm{x}}-10 \mathrm{wt} \% \mathrm{CaO}$ SEM morphologies: (d) $\times 2500,($ e $) \times 5000$, (f) $\times 10,000$.

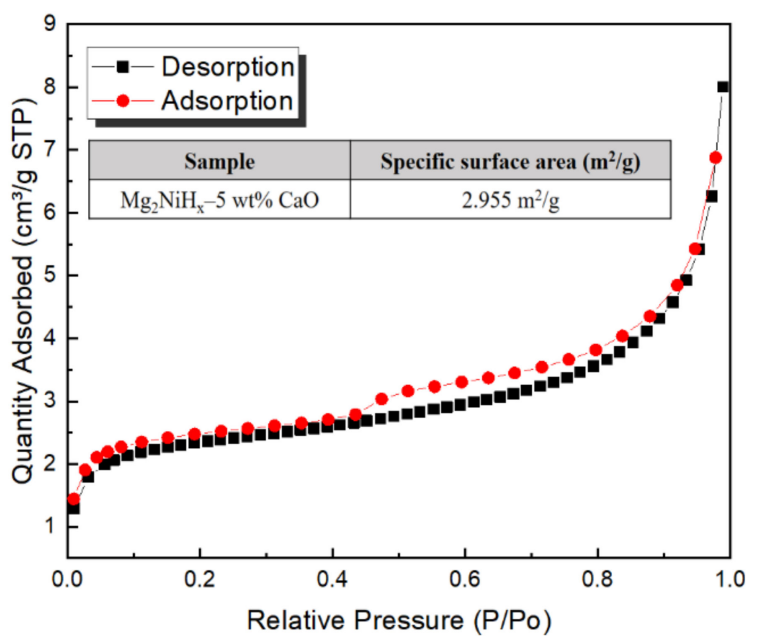

(a)

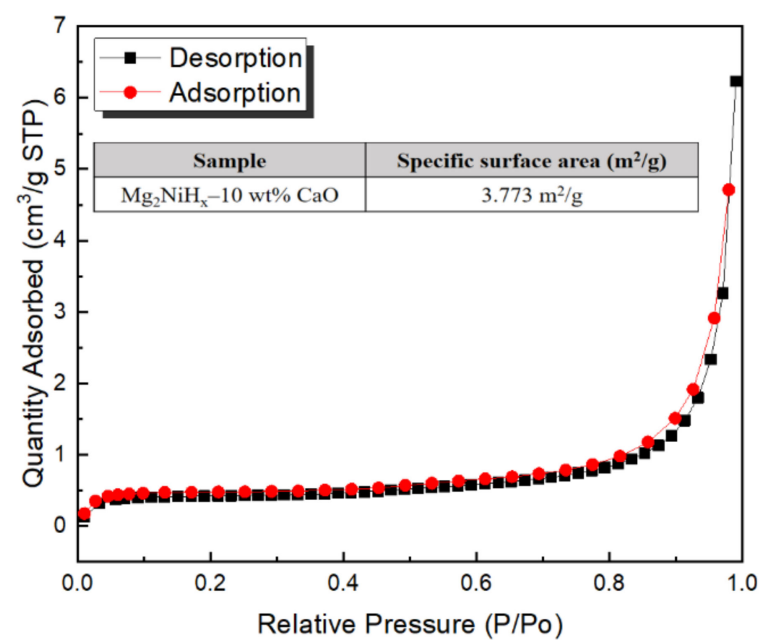

(b)

Figure 4. Bruner-Emmett-Teller surface area analysis results for (a) $\mathrm{Mg}_{2} \mathrm{NiH}_{\mathrm{x}}-5 \mathrm{wt} \% \mathrm{CaO}$ (reprinted with permission from [23]. Copyright 2021 Copyright Shin, H.-W.), (b) $\mathrm{Mg}_{2} \mathrm{NiH}_{\mathrm{x}}-10 \mathrm{wt} \% \mathrm{CaO}$.

Figure $5 \mathrm{a}$ is the result of measuring the hydrogen absorption reaction kinetics of $\mathrm{Mg}_{2} \mathrm{NiH}_{\mathrm{x}}-10 \mathrm{wt} \% \mathrm{CaO}$ composites under each temperature $(423,523,623 \mathrm{~K})$ condition. After the hydrogen pressure was kept constant at 3.0 $\mathrm{MPa}$, the change in hydrogen absorp- 
tion with time for $1 \mathrm{~h}$ was investigated. As a result, hydrogen absorption was highest at $623 \mathrm{~K}$ and lowest at $423 \mathrm{~K}$. When the effective hydrogen storage amount was calculated through the hydrogenation kinetics curve, $\mathrm{Mg}_{2} \mathrm{NiH}_{\mathrm{x}}-5 \mathrm{wt} \% \mathrm{CaO}$ at 423,523 , and $623 \mathrm{~K}$ temperatures were $0.51 \mathrm{wt} \%, 0.93 \mathrm{wt} \%$, and $1.12 \mathrm{wt} \% . \mathrm{Mg}_{2} \mathrm{NiH}_{\mathrm{x}}-10 \mathrm{wt} \% \mathrm{CaO}$ showed $0.52 \mathrm{wt} \%, 1.21 \mathrm{wt} \%, 1.59 \mathrm{wt} \%$ of hydrogen absorption, through which it was confirmed that the hydrogenation reaction rate increased as $\mathrm{CaO}$ was added. Figure $5 \mathrm{~b}$ is the result calculated through the van' $\mathrm{t}$ Hoff equation from the result of the hydrogen absorption reaction rate. The absorption enthalpy $(\Delta \mathrm{H})$ of the $\mathrm{Mg}_{2} \mathrm{NiH}_{\mathrm{x}}-5 \mathrm{wt} \% \mathrm{CaO}$ was calculated as a value of $14.138 \pm 0.67 \mathrm{~kJ} / \mathrm{mol}$ [23], and the $\mathrm{Mg}_{2} \mathrm{NiH}_{\mathrm{x}}-10 \mathrm{wt} \% \mathrm{CaO}$ showed a relatively high value of $20.617 \pm 0.14 \mathrm{~kJ} / \mathrm{mol}$. Therefore, $\mathrm{Mg}_{2} \mathrm{NiH}_{\mathrm{x}}-10 \mathrm{wt} \% \mathrm{CaO}$ composites exhibited superior kinetics characteristics compared to $\mathrm{Mg}_{2} \mathrm{NiH}_{\mathrm{x}}-5 \mathrm{wt} \% \mathrm{CaO}$ due to the high heat of reaction.

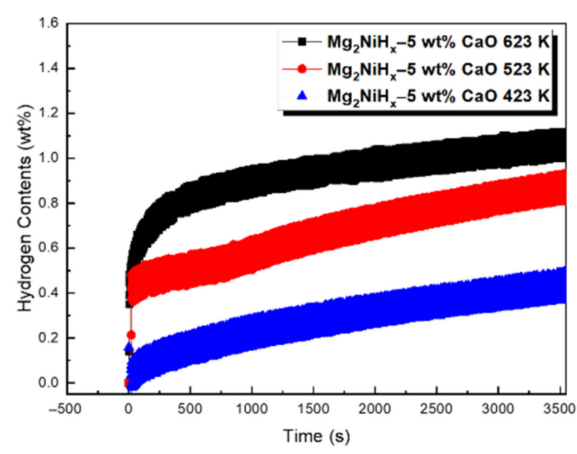

(a)

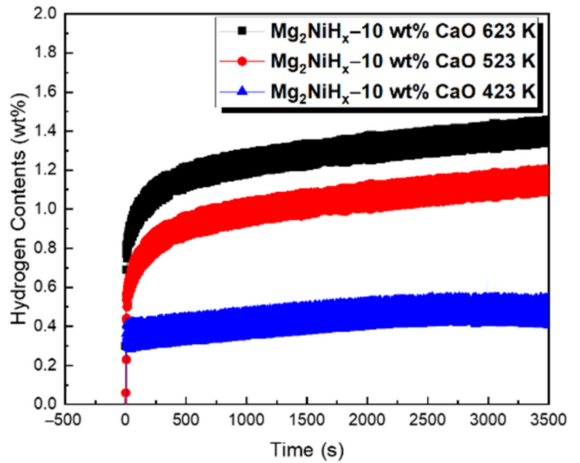

(b)

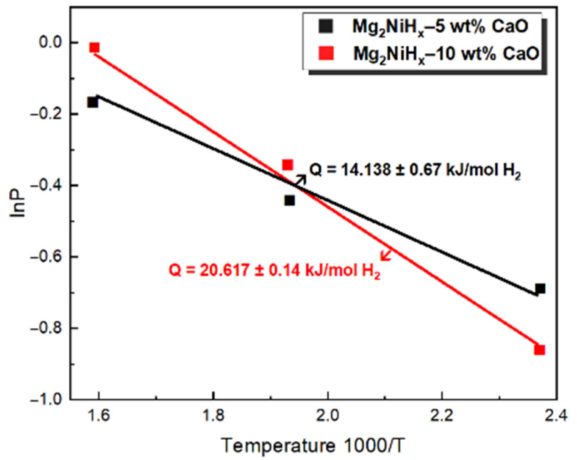

(c)

Figure 5. Hydrogen absorption kinetics of (a) $\mathrm{Mg}_{2} \mathrm{NiH}_{\mathrm{x}}-5 \mathrm{wt} \% \mathrm{CaO}$ (reprinted with permission from [23]. Copyright 2021 Copyright Shin, H.-W.), (b) $\mathrm{Mg}_{2} \mathrm{NiH}_{\mathrm{x}}-10 \mathrm{wt} \% \mathrm{CaO}$, (c) calculation of van't Hoff plots on $\mathrm{Mg}_{2} \mathrm{NiH}_{\mathrm{x}}-5 \mathrm{wt} \% \mathrm{CaO}$ (reprinted with permission from [23]. Copyright 2021 Copyright Shin, H.-W.) and $\mathrm{Mg}_{2} \mathrm{NiH}_{\mathrm{x}}-10 \mathrm{wt} \% \mathrm{CaO}$.

\subsection{Life Cycle Assessment on Composites Prepared}

The LCA process uses classification, characterization, and normalization. The environmental impact is then derived according to this order, and major issues are then identified, based on this. In our work, the classification involved 10 impact categories, which included abiotic resource depletion (ARD), global warming potential (GWP), stratospheric ozone depletion potential (ODP), acidification potential (ACP), and eutrophication potential (EUP), ecotoxicity potential (ETP), and human toxicity potential (HTP). Among these, ecological toxicity included fresh-water aquatic ecotoxicity potential (FAETP), marine aquatic ecotoxicity potential (MAETP), and terrestrial ecotoxicity potential (TETP). In addition, 11 impact categories are included in human health, ecosystem quality, and resources [27].

In Figure 6, the normalization result of applying CML 2001 to the $\mathrm{Mg}_{2} \mathrm{NiH}_{\mathrm{x}}-\mathrm{CaO}$ composite material is plotted as one graph through the comparison target. As a result, it was confirmed that both $\mathrm{Mg}_{2} \mathrm{NiH}_{\mathrm{x}}-5,10 \mathrm{wt} \% \mathrm{CaO}$ composites showed the highest GWP value, followed by ACP and ARD. As can be seen from the graph, $\mathrm{Mg}_{2} \mathrm{NiH}_{\mathrm{x}}-10 \mathrm{wt} \%$ $\mathrm{CaO}$ overall showed a higher value than $\mathrm{Mg}_{2} \mathrm{NiH}_{\mathrm{x}}-5 \mathrm{wt} \% \mathrm{CaO}$, which is considered to be the effect of $\mathrm{CaO}$ addition. In addition, the highest GWP value appears to be the use of electricity through multiple mechanical alloying (MA) processes. Therefore, it is necessary to study a process that can be synthesized by performing a single MA process when manufacturing $\mathrm{Mg}_{2} \mathrm{NiH}_{\mathrm{x}}-\mathrm{CaO}$ composite materials, and to find a way to lower the global warming index by reducing electricity consumption.

Figure 7 shows the $\mathrm{Mg}_{2} \mathrm{NiH}_{\mathrm{x}}-\mathrm{CaO}$ composites as a graph using the Eco-Indicator 99' (EI99) methodology. As a result of the graph, fossil fuels were the largest. In addition, the impact categories were measured in the order of climate change and respiratory. In particular, $\mathrm{Mg}_{2} \mathrm{NiH}_{\mathrm{x}}-10 \mathrm{wt} \% \mathrm{CaO}$ shows the greatest difference between fossil fuels and climate change values when compared to $\mathrm{Mg}_{2} \mathrm{NiH}_{\mathrm{x}}-5 \mathrm{wt} \% \mathrm{CaO}$, which appears to be 
highly related to global warming, similar to the previous CML 2001 methodology. In view of the fact that the remaining environmental impact figures show almost similar values, it is judged that the additional amount of $5 \mathrm{wt} \% \mathrm{CaO}$ does not have a significant effect. As mentioned above, efforts are required to minimize unnecessary energy consumption during the manufacturing process and to reduce the use of electricity as much as possible to reduce a large amount of environmental load.

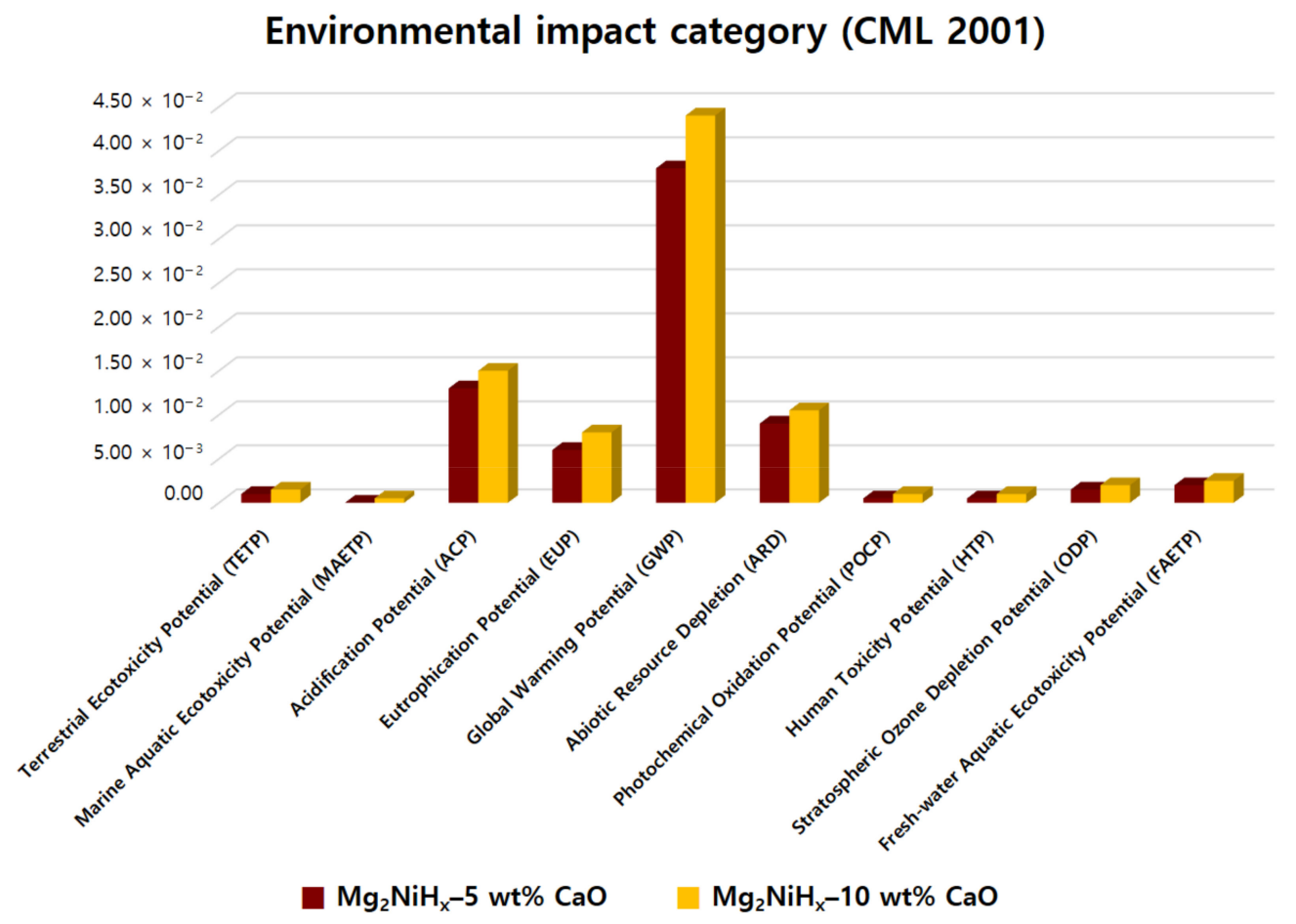

Figure 6. Normalization of $\mathrm{Mg}_{2} \mathrm{NiH}_{\mathrm{x}}-5 \mathrm{wt} \% \mathrm{CaO}$ (reprinted with permission from [28]. Copyright 2021 Copyright Shin, H. W) and $\mathrm{Mg}_{2} \mathrm{NiH}_{\mathrm{x}}-10 \mathrm{wt} \% \mathrm{CaO}$ composites by environmental impact category (CML 2001).

Figure 8 shows the $\mathrm{CO}_{2}$ value of global warming impact by synthesized $\mathrm{Mg}_{2} \mathrm{NiH}_{\mathrm{x}}-$ $\mathrm{CaO}$ composites. The carbon dioxide emission of $\mathrm{Mg}_{2} \mathrm{NiH}_{\mathrm{x}}-5 \mathrm{wt} \% \mathrm{CaO}$ [28] was $0.0378 \mathrm{~kg}$, $\mathrm{Mg}_{2} \mathrm{NiH}_{\mathrm{x}}-10 \mathrm{wt} \% \mathrm{CaO}$ was $0.0413 \mathrm{~kg}$. Accordingly, it was found that $\mathrm{Mg}_{2} \mathrm{NiH}_{\mathrm{x}}-10 \mathrm{wt} \%$ $\mathrm{CaO}$ with a higher $\mathrm{CaO}$ content had higher $\mathrm{CO}_{2}$ emissions than $\mathrm{Mg}_{2} \mathrm{NiH}_{\mathrm{x}}-5 \mathrm{wt} \% \mathrm{CaO}$. In order to decrease the occurrence of such global warming, various efforts for sustainable development have been reported in developed countries around the world to prevent environmental pollution by reducing $\mathrm{CO}_{2}$ emissions [29]. Therefore, it is necessary to improve the manufacturing process of the $\mathrm{Mg}_{2} \mathrm{NiH}_{\mathrm{x}}-\mathrm{CaO}$ composites and to find the optimum mass ratio that can reduce the amount of $\mathrm{CaO}$ and increase the efficiency. 


\section{Environmental impact category Eco-Indicator 99' (El99)}

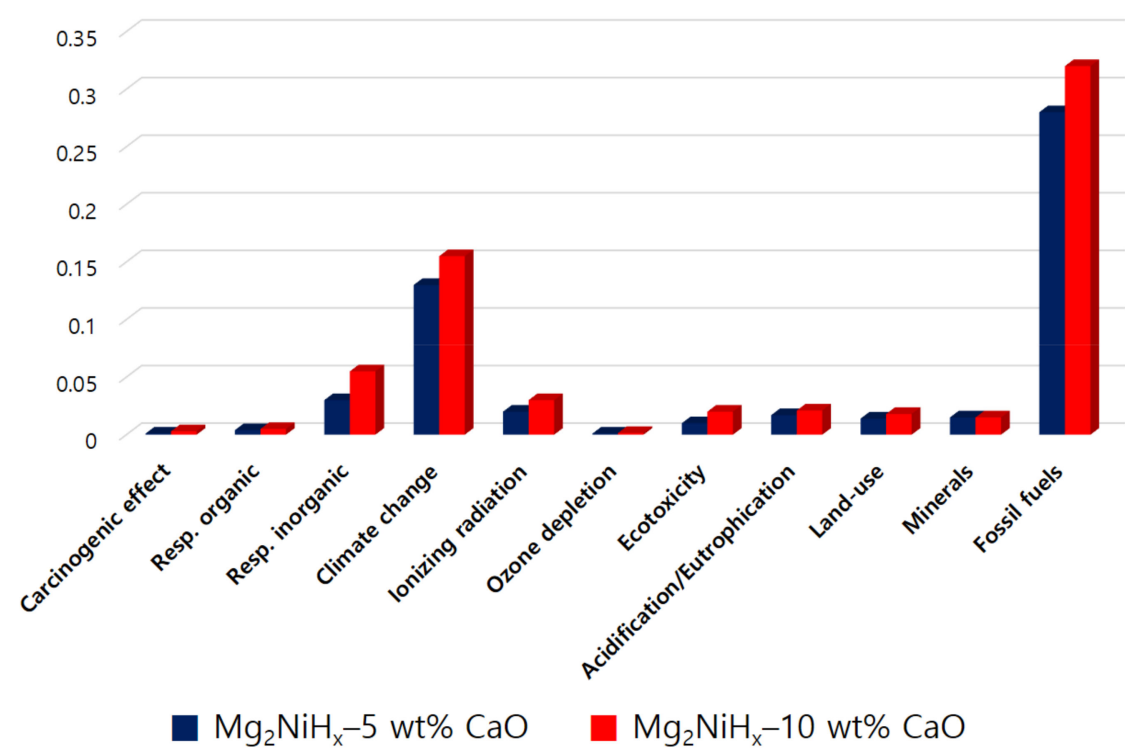

Figure 7. Normalization of $\mathrm{Mg}_{2} \mathrm{NiH}_{\mathrm{x}}-5 \mathrm{wt} \% \mathrm{CaO}$ (reprinted with permission from [28]. Copyright 2021 Copyright Shin, H.-W.) and $\mathrm{Mg}_{2} \mathrm{NiH}_{\mathrm{x}}-10 \mathrm{wt} \% \mathrm{CaO}$ compo-sites by environmental impact category Eco-Indicator 99' (EI99).

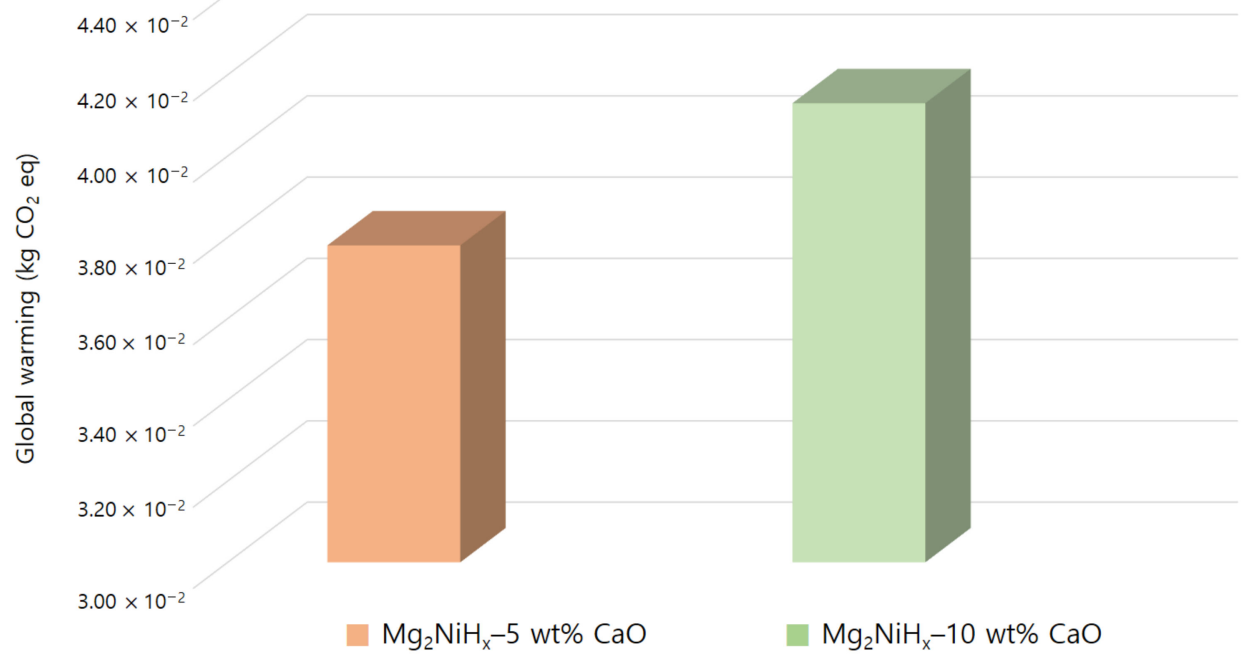

Figure 8. Comparing $\mathrm{CO}_{2}$ value of global warming impact by $\mathrm{Mg}_{2} \mathrm{NiH}_{\mathrm{x}}-\mathrm{CaO}$ composites.

\section{Conclusions}

In this study, environmental pollution caused by the amount of $\mathrm{CaO}$ added during the synthesis of $\mathrm{Mg}_{2} \mathrm{NiH}_{\mathrm{x}}-\mathrm{CaO}$ composites was evaluated through the LCA process. We generated 11 impact categories assessed using the EI99 methodology and 10 impact categories assessed using the CML 2001 methodology. As a result of the CML 2001 methodology, $\mathrm{Mg}_{2} \mathrm{NiH}_{\mathrm{x}}-5,10 \mathrm{wt} \% \mathrm{CaO}$ had the highest GWP value, and the resulting carbon dioxide generation was $0.0378 \mathrm{~kg}\left(\mathrm{Mg}_{2} \mathrm{NiH}_{\mathrm{x}}-5 \mathrm{wt} \% \mathrm{CaO}\right), 0.0413 \mathrm{~kg}\left(\mathrm{Mg}_{2} \mathrm{NiH}_{\mathrm{x}}-10 \mathrm{wt} \% \mathrm{CaO}\right)$. In addition, it can be seen that all environmental load values were overall higher depending on the amount of $\mathrm{CaO}$ added. Accordingly, in order to lower the global warming potential, it is necessary to save electricity or to find a more environmentally friendly material than $\mathrm{CaO}$. The EI99 methodology showed the highest levels of fossil fuels, followed by climate 
change, followed by respiratory. This seems to be closely related to the aforementioned global warming, and the remaining environmental load values are very low and show similar results, so it is judged that the amount of $\mathrm{CaO}$ added did not have a significant effect. Therefore, efforts to reduce electricity usage as much as possible are expected to minimize unnecessary energy consumption in the synthesis process and to reduce large amounts of environmental impact figures. Ultimately, when comparing $\mathrm{Mg}_{2} \mathrm{NiH}_{\mathrm{x}}-5,10 \mathrm{wt} \% \mathrm{CaO}$ composites, $\mathrm{Mg}_{2} \mathrm{NiH}_{\mathrm{x}}-10 \mathrm{wt} \% \mathrm{CaO}$ was better in terms of hydrogenation kinetics, but $\mathrm{Mg}_{2} \mathrm{NiH}_{\mathrm{x}}-5 \mathrm{wt} \% \mathrm{CaO}$ showed better results in terms of environment. Therefore, it can be seen that the hydrogenation kinetics and the environmental load value are inversely proportional depending on the amount of $\mathrm{CaO}$ added. Ultimately, it is necessary to explore materials that exhibit excellent performance while using eco-friendly materials, and research should be conducted considering environmental factors, not performance-oriented, when making out an alloy.

Author Contributions: H.-W.S., J.-H.H., E.-A.K. and T.-W.H. conceived and designed the experiments and hydrogenation kinetics and life cycle assessment; H.-W.S. performed the experiments and wrote the paper; J.-H.H. and E.-A.K. assisted the experiments; T.-W.H. advised H.-W.S. on experimental results and edited the paper. All authors have read and agreed to the published version of the manuscript.

Funding: This study was supported by the National Research Foundation of Korea (NRF) grant funded by the Korea government (MSIT) (No. 2019R1F1A1041405); the Ministry of SMEs and Startups, Republic of Korea (S3045542); and the Basic Science Research Capacity Enhancement Project (National Research Facilities and Equipment Center) through the Korea Basic Science Institute funded by the Ministry of Education (Grant No. 2019R1A6C1010047).

Institutional Review Board Statement: Not applicable.

Informed Consent Statement: Not applicable.

Data Availability Statement: The data presented in this study are available on request from the corresponding author.

Conflicts of Interest: The authors declare no conflict of interest.

\section{Nomenclature}

Eco-Indicator 99'

ISO 14000 series

Global warming potential (GWP)

ODP (ozone layer depletion potential)

AP (acidification potential)

EP (eutrophication potential)

ETP (ecotoxicity potential)

Human toxicity potential (HTP)
As a lifecycle impact assessment tool developed by Consultants B.V., designers can perform environmental assessments of products by calculating environmental mark scores for used materials and processes. Environmental management life cycle assessment principles and framework, Korean Agency for Technology and Standard, 2007. In a relative sense, it is a type of index based on a simplified radiative characteristic that can be used to measure the possible future impacts of the evolution of various gases on the climate system in the future. It is a numerical expression of the degree of destruction of compounds that destroy ozone. Based on the ozone depletion capacity of CFC-11 as 1, the destructive power of the remaining chemicals was assumed. Acidification occurs primarily when nitrogen oxides $\left(\mathrm{NO}_{\mathrm{x}}\right)$ and sulfur dioxide gas $\left(\mathrm{SO}_{2}\right)$ interact with other atmospheric components. It refers to a phenomenon in which nutrients are excessively supplied to water due to the inflow of chemical fertilizers or sewage, causing rapid growth or extinction of plants and killing organisms by taking away oxygen from the water.

Ecotoxicity refers to the ecological impacts of chemicals, pesticides, and pharmaceuticals on freshwater organisms and the possible risks to the aquatic ecosystem.

Total emissions are assessed in terms of benzene and toluene equivalents, but potential doses include multiple routes of exposure, including inhalation, ingestion, and dermal contact of fish and meat. 


\section{References}

1. Ryi, S.K.; Han, J.Y.; Kim, C.H.; Lim, H.; Jung, H.Y. Technical Trends of Hydrogen Production. Clean Technol. 2017, $23,121-132$.

2. Balat, M. Potential Importance of Hydrogen as a Future Solution to Environmental and Transportation Problems. Int. J. Hydrogen Energy 2008, 33, 4013-4029. [CrossRef]

3. Demirbas, A.; Dincer, K. Sustainable Green Diesel: A Futuristic View. Energy Sources Part A 2008, 30, 1233-1241. [CrossRef]

4. Yun, C.W. Liquid Organic Hydrogen Carrier (LOHC) technology for realization of a hydrogen society. News Inf. Chem. Eng. 2019, 37, 471-485.

5. Lee, P.J.; Kim, J.W.; Bae, K.K.; Jeong, S.U.; Kang, K.S.; Jung, K.J.; Park, C.S.; Kim, Y.H. Heat Transfer Characteristics and Hydrogen Storage Kinetics of Metal Hydride-Expended Graphite Composite. Trans. Korean Hydrog. New Energy Soc. 2020, 31, 564-570. [CrossRef]

6. Zhi, C.; Chao, T.; Hui, P.; Huabin, Y. Rehydrogenation performance of an $\mathrm{MgH}_{2}-\mathrm{Nb}_{2} \mathrm{O}_{5}$ system modified by heptane and acetone. Int. J. Hydrogen Energy 2010, 35, 8289-8294. [CrossRef]

7. Yang, W.N.; Shang, C.X.; Guo, Z.X. Site density effect of Ni particles on hydrogen desorption of MgH 2 . Int. J. Hydrogen Energy 2010, 35, 4534-4542. [CrossRef]

8. Park, H.R.; Song, M.Y. Reaction Rate with Hydrogen and Hydrogen-storage Capacity of an $80 \mathrm{Mg}+14 \mathrm{Ni}+6 \mathrm{TaF} 5 \mathrm{Alloy}$ Prepared by High-energy Ball Milling in Hydrogen. Trans. Korean Hydrog. New Energy Soc. 2017, 28, 137-143.

9. Jang, S.Y.; Kang, K.M.; Hayato, O.; Shigeharu, K. Mg-based hydrogen storage alloy. Gas Ind. Technol. 2003,6 , $40-47$.

10. Berlin, J. Environmental life cycle assessment (LCA) of Swedish semi-hard cheese. Int. Dairy J. 2002, 12, 939-953. [CrossRef]

11. Lee, S.H.; Jo, Y.M. Review of National Policies on the Utilization of Waste Metal Resources. KIC News 2010, 13, 2-9.

12. Lee, S.S.; Hong, T.W. Life Cycle Assessment for Proton Conducting Ceramics Synthesized by the Sol-Gel Process. Materials 2014, 7, 6677-6685. [CrossRef] [PubMed]

13. Rhys, J.T.; Marco, L.L.; Andrew, N.; Kevin, D.P.; Ian, H. An evaluation of life cycle assessment and its application to the closed-loop recycling of carbon fibre reinforced polymers. Compos. Part B Eng. 2020, 184, 107665.

14. Lee, N.R.; Lee, S.S.; Kim, K.I.; Hong, T.W. Environmental Assessment of Chemically Strengthened Glass for Touch Screen Panel by Material Life Cycle Assessment. Clean Technol. 2012, 18, 301-306. [CrossRef]

15. Lee, S.S.; Lee, N.R.; Kim, K.I.; Hong, S.J.; Hong, T.W. MLCA (Material Life Cycle Assessment) for ITO Recycling. Mater. Sci. Forum. 2012, 724, 12-16. [CrossRef]

16. Hong, T.W.; Lim, J.W.; Kim, S.K.; Kim, Y.J.; Park, H.S. Formation of $\mathrm{Mg}_{2} \mathrm{NiH}_{\mathrm{x}}$ hydrogen absorbing materials by hydrogen induced mechanical alloying. J. Korean Inst. Met. Mater. 1999, 37, 369-376.

17. Yasin, S.; Behary, N.; Perwuelz, A.; Guan, J. Life cycle assessment of flame retardant cotton textiles with optimized end-of-life phase. J. Clean. Prod. 2018, 172, 1080-1088. [CrossRef]

18. International Organisation for Standardisation. ISO 14040: 2006_Environmental Management_Life Cycle Assessment-Principles and Framework; International Organisation for Standardisation: Geneva, Switzerland, 2006; Volume 1, pp. 1-32.

19. International Organisation for Standardisation. ISO 14044: 2006_Environmental Management_Life Cycle Assessment—Requirements and Guidelines; International Organisation for Standardisation: Geneva, Switzerland, 2006; Volume 1, pp. 1-46.

20. Meng, F.; McKechnie, J.; Turner, T.A.; Pickering, S.J. Energy and environmental assessment and reuse of fluidised bed recycled carbon fibres. Compos. Part A Appl. Sci. Manuf. 2017, 100, 206-214. [CrossRef]

21. Demertzi, M.; Silvestre, J.D.; Durão, V. Life cycle assessment of the production of composite sandwich panels for structural floor's rehabilitation. Eng. Struct. 2020, 221, 111060. [CrossRef]

22. Jeong, S.J.; Lee, J.Y.; Shon, J.S.; Hur, T. Life Cycle Assessments of Long-term and Short-term Environmental Impacts for the Incineration of Spent Li-ion Batteries (LIBs). J. Korean Ind. Eng. Chem. 2006, 17, 163-169.

23. Shin, H.W.; Hwang, J.H.; Kim, E.A.; Hong, T.W. Hydriding Kinetics on $\mathrm{Mg}_{2} \mathrm{NiH}_{\mathrm{x}}-5 \mathrm{wt} \%$ CaO Composites. Trans. Korean Hydrog. New Energy Soc., submitting.

24. Lee, J.K.; Kim, S.K. Effect of $\mathrm{CaO}$ addition on the ignition resistance of Mg-Al alloys. Mater. Trans. 2011, 52, 1483-1488. [CrossRef]

25. Huang, Z.G.; Guo, Z.P.; Calka, A.; Wexler, D.; Lukey, C.; Liu, H.K. Effects of iron oxide $\left(\mathrm{Fe}_{2} \mathrm{O}_{3}, \mathrm{Fe}_{3} \mathrm{O}_{4}\right)$ on hydrogen storage properties of Mg-based composites. J. Alloys Compd. 2006, 422, 299-304. [CrossRef]

26. Sahoo, S.K.; Parveen, S.; Panda, J.J. The present and future of nanotechnology in human health care. Nanomed. Nano Technol. Biol. Med. 2007, 3, 20-31. [CrossRef] [PubMed]

27. Rashidi, A.M.; Nouralishahi, A.; Khodadadi, A.A.; Mortazzavi, Y.; Karimi, A.; Kashefi, K. Modification of single wall carbon nanotubes (SWNT) for hydrogen storage. Int. J. Hydrogen Energy 2010, 35, 9489-9495. [CrossRef]

28. Shin, H.W.; Hwang, J.H.; Kim, E.A.; Hong, T.W. Material Life Cycle Assessment on $\mathrm{Mg}_{2} \mathrm{NiH}_{\mathrm{x}}-5$ wt $\%$ CaO Hydrogen Storage Composites. Clean. Technol., submitting.

29. Kim, M.G.; Son, J.T.; Hong, T.W. Evaluation of TiN-Zr Hydrogen Permeation Membrane by MLCA (Material Life Cycle Assessment). Clean. Technol. 2018, 24, 9-14. 